\title{
LXIII. Abstract of chemico-physiological researches
}

\section{Joseph Scherer M.D.}

To cite this article: Joseph Scherer M.D. (1842) LXIII. Abstract of chemicophysiological researches, Philosophical Magazine Series 3, 20:132, 412-417, DOI: 10.1080/14786444208650600

To link to this article: http://dx.doi.org/10.1080/14786444208650600

曲 Published online: 01 Jun 2009.

Submit your article to this journal $₫$

Џ Article views: 2

Q View related articles 두 


\section{Abstract of Chemico-Physiological Researches by Joseph Scherer, M.D.}

[Continued from p. 319, and concluded.]

Of Albumen.

A. DURE albumen from serum, dried without coagulation, was digested successively with water at $86^{\circ}$ Fahrenheit, alcohol and æther, and then analysed.

B. Serum of the blood, merely boiled successively with water, alcohol and æther, until nothing more was dissolved.

C. Albumen from hens' eggs, dried without coagulation, was digested with water at $86^{\circ}$, which dissolved the pure albumen (as in A), which was then precipitated by alcohol, and boiled with alcohol and æether.

These specimens were analysed by combustion with chromate of lead, and the nitrogen determined both by Will's method and directly; the results are,

A.

Carbon ..... 55*461.

Hydrogen ... 7.201

Nitrogen .... 15.673

$\left.\begin{array}{c}\text { Oxygen, sulphur } \\ \text { and phosphorus }\end{array}\right\} 21 \cdot 665$

$100 \cdot 000$
B.

$55 \cdot 097$

$6 \cdot 880$

$15 \cdot 681$

$22 \cdot 342$

$100 \cdot 000$
C.

$55 \cdot 000$

$7 \cdot 073$

$15 \cdot 920$

$22 \cdot 007$

$100 \cdot 000$

The albumen derived from various morbid secretions was also analysed by the same methods; from the fluid of hydrocele and of ordinary ascites; from pus (the ashes of which contained a little iron); from a congestive abscess. The analytical results per cent. were identical with those for normal albumen already given.

\section{Casein.}

A. Fresh milk being precipitated by alcohol, the curd was taken out and boiled repeatedly in alcohol and æther, until all traces of butter were removed. To deprive it totally of sugar it was then again boiled with water, and finally dried at $212^{\circ}$ Fahr.

B. Milk which had become spontaneously somewhat sour, was heated; it then curdled. The curd was boiled in water, alcohol and æether, as long as anything was dissolved, and then dried at $212^{\circ}$.

C. Casein prepared by Liebig, by precipitating milk with acetic acid, dissolving the precipitate by carbonate of soda, and again precipitating; then extracting the butter by boiling æther. 
D. The material (coagulating by heat, like albumen) which remains dissolved in milk which has become sour, was boiled with alcohol and æther, and dried.

Of these specimens of casein,

$\begin{array}{ccccc}\text { A } & \text { gives } & 10.0 & \text { per cent. of ashes . } \\ \text { B } & \ldots & 2.0 & \ldots & \ldots \\ \text { C } & \ldots & 1.5 & \ldots & \ldots \\ \text { D } & \ldots & 2.0 & \ldots & \ldots\end{array}$

The methods of analysis being the same as in the former instances, the results were,-

A.

B.

C.

D.

\begin{tabular}{|c|c|c|c|c|}
\hline \multirow{5}{*}{$\begin{array}{l}\text { Carbon .. } \\
\text { Hydrogen } \\
\text { Nitrogen } \\
\text { Oxygen } \\
\text { Sulphur }\end{array}$} & $54 \cdot 825$ & $54 \cdot 721$ & $54 \cdot 580$ & $54 \cdot 507$ \\
\hline & $7 \cdot 153$ & $7 \cdot 239$ & $7 \cdot 952$ & 6.913 \\
\hline & $15 \cdot 628$ & $15 \cdot 724$ & $15^{\circ} 696$ & $15 \cdot 670$ \\
\hline & $22 \cdot 5$ & $22 \cdot 316$ & $22 \cdot 372$ & 22.910 \\
\hline & & $P$ & & \\
\hline
\end{tabular}

Dr. Scherer prepared this body according to Mulder's method, by solution in caustic potash liquor and precipitation by acetic acid. The results with protein from three different sources agree very well with those of Mulder, and are as follows :-

\begin{tabular}{|c|c|c|c|}
\hline & $\begin{array}{l}\text { Protein from } \\
\text { crystalline lens. } \\
\text {. } 55 \cdot 300\end{array}$ & $\begin{array}{l}\text { Protein from } \\
\text { albumen. } \\
55 \cdot 160\end{array}$ & $\begin{array}{l}\text { Protein from } \\
\text { fibrine. } \\
54 \cdot 848\end{array}$ \\
\hline Hydrogen & 6.940 & 7.055 & 6.959 \\
\hline Nitrogen. & $16 \cdot 216$ & $15 \cdot 966$ & $15 \cdot 84.7$ \\
\hline & $21 \cdot 544$ & $21 \cdot 819$ & $22 \cdot 346$ \\
\hline & $100 \cdot 000$ & $100 \cdot 000$ & $100 \cdot 000$ \\
\hline
\end{tabular}

As the compounds of protein do not admit of our deducing any positive rational formula for protein, Liebig proposes the empirical formula $\mathrm{C}_{48} \mathrm{H}_{36} \mathrm{~N}_{6} \mathrm{O}_{14}$, which gives a per cent. composition coinciding with the results of the above analyses.

Having thus determined the composition of the fundamental materials of the animal organization, Dr. Scherer proceeds to examine the secondary tissues. These are merely to be considered as products of animal life, and are not met with in vegetable structures, whereas the former class exist equally in both departments of organized nature. The substances to be analysed were obtained in the condition of greatest anatomical purity, and carefully freed from all intermixed fat, \&c. by such chemical means as were least likely to alter their own texture. Although such textures are not anatomically homogeneous, but under the microscope still show 
traces of the presence of nerves and blood-vessels, yet these could not be supposed to modify their composition in any important degree, as their quantity is excessively minute, and their composition not very different from that of the tissue under examination.

\section{Tissues which yield Gelatine.}

The substances selected as yielding pure gelatine, were isinglass and the tendons of the feet of young calves. They were both perfectly soluble in boiling water. The isinglass, when freed from all traces of fat by boiling in æther, and dried at $212^{\circ}$, gave by incineration 0.5 per cent. of ashes. The calves' tendons macerated for some time with a solution of nitre to remove any investing membrane, and then washed perfectly out with pure water, and boiled with alcohol and æther, gave on incineration $1 \cdot 6$ per cent. of ashes.

Each material was analysed several times, but the following results need only be given, the others were almost coincident:-

$$
\begin{aligned}
& \text { Isinglass. Calves' tendons. } \\
& \text { Carbon . . . 50.557 50.960 } \\
& \text { Hydrogen . . 6.903 7.188 } \\
& \text { Nitrogen . . 18.790 18.320 } \\
& \text { Oxygen } \cdots \frac{23 \cdot 750}{100 \cdot 000} \quad \frac{23.532}{100 \cdot 000}
\end{aligned}
$$

The sclerotic coat of the eye is composed as the gelatinous tissues, although in its insolubility in boiling water it resembles those tissues which yield chondrin. It gave-

$$
\left.\begin{array}{l}
\text { Carbon ..... } 50.995 \\
\text { Hydrogen . . . } 7.075 \\
\text { Nitrogen . . . 18.723 } \\
\text { Oxygen ... 23.207 }
\end{array}\right\} 100.000 .
$$

If we take double the carbon which exists in the formula already given for protein as a standard, and calculate from it a formula to express the composition of gelatine as given above, we obtain $\mathrm{C}_{96} \mathrm{H}_{82} \mathrm{~N}_{15} \mathrm{O}_{36}$, and subtracting from it two equivalents of protein, there remain $3 . \mathrm{N} \mathrm{H}_{3}$ with $\mathrm{HO}$ and $7 \mathrm{O}$, for

$$
\left.\begin{array}{rlll}
\mathrm{C}_{96} & \mathrm{H}_{82} & \mathrm{~N}_{15} & \mathrm{O}_{36} \\
\mathrm{C}_{72} & \mathrm{~N}_{12} & \mathrm{O}_{28}
\end{array}\right\}=\mathrm{H}_{10} \mathrm{~N}_{3} \mathrm{O}_{8} .
$$

Tissues which yield Chondrin.

Chondrin was shown by its discoverer Müller to exist in the permanent cartilages, in the bones before ossification, in the cornea of the eye, and also in some morbid enlargements of the bones.

For analysis, Dr. Scherer selected the cartilages of the ribs 
of young calves, and the cornea. They were digested with water and some saltpetre to dissolve out all albuminous material, and then boiled with alcohol and æther to remove the fat.

This chondrin dried at $212^{\circ}$ contained $6^{\circ} 6$ per cent. of ashes.

Analysed by the usual methods the results were-

\begin{tabular}{|c|c|c|c|}
\hline & \multicolumn{2}{|c|}{ Ribs. } & Cornea. \\
\hline Carbon ........ & $\begin{array}{c}\text { I. } \\
49 \cdot 496\end{array}$ & ${ }_{50 \cdot 895}^{11 .}$ & $\begin{array}{c}\text { III. } \\
49 \cdot 529\end{array}$ \\
\hline Hydrogen...... & $7 \cdot 333$ & 6.962 & 7.097 \\
\hline Nitrogen ...... & $14 \cdot 908$ & $14 \cdot 908$ & $14 \cdot 399$ \\
\hline Oxygen.......... & $28 \cdot 463$ & $27 \cdot 235$ & $28 \cdot 982$ \\
\hline & $100 \cdot 000$ & $\overline{100 \cdot 000}$ & $\overline{100 \cdot 000}$ \\
\hline
\end{tabular}

If we take the carbon here as being of the same magnitude as that of protein, the formula resulting from these analyses is $\mathrm{C}_{48} \mathrm{H}_{40} \mathrm{~N}_{6} \mathrm{O}_{20}$, which differs from protein by containing 4. $\mathrm{H} \mathrm{O}$ and $2 . \mathrm{O}$ in excess.

The Elastic Coat of the Arteries.

This tissue, purified in the same manner as the other substances analysed, and dried at $212^{\circ}$, gave $1 \cdot 7$ per cent. of ashes.

The analysis of it yielded-

\begin{tabular}{lrr} 
& T. & \multicolumn{1}{c}{ 1t. } \\
Carbon ........ & $53 \cdot 750$ & $53 \cdot 393$ \\
Hydrogen ...... & $7 \cdot 079$ & 6.973 \\
Nitrogen $\ldots . . .$. & $15 \cdot 360$ & $15 \cdot 360$ \\
Oxygen ......... & $23 \cdot 811$ & $24 \cdot 274$ \\
\hline $100 \cdot 000$ & $100 \cdot 000$
\end{tabular}

The formula given by these results is $\mathrm{C}_{48} \mathrm{H}_{38} \mathrm{~N}_{6} \mathrm{O}_{16}$, and deducting thence that of protein, $\mathrm{C}_{48} \mathrm{H}_{36} \mathrm{~N}_{6} \mathrm{O}_{14}$, it appears that the elastic coat of arteries differs from protein in containing plus the elements of two atoms of water.

\section{Corneous Tissues.}

This substance presents itself in two forms, membranous and compact. The first constitutes the epidermis and the epithelium in its various forms; the latter constitutes hair, horns, nails, \&c.

A. Membranous Corneous Tissue.-For analysis, Dr. Scherer selected the epidermis of the sole of the foot where it is thickest and most easily separated. It was purified by boiling in water, alcohol and æther. Dried at $212^{\circ}$, it gave 1.0 per cent. of ashes.

It was analysed as usual, except that the nitrogen was determined directly by volume in the old manner. 
The results were,-

\begin{tabular}{lrrr} 
& \multicolumn{1}{c}{ I. } & \multicolumn{1}{c}{ II. } \\
Carbon ...... & $51 \cdot 036$ & $50 \cdot 752$ \\
Hydrogen... & $6 \cdot 801$ & $6 \cdot 761$ \\
Nitrogen ... & $17 \cdot 225$ & $17 \cdot 225$ \\
Oxygen....... & $\mathbf{2 4 \cdot 9 3 8}$ & $\frac{25 \cdot 262}{100 \cdot 000}$
\end{tabular}

B. Compact Corneous Tissue.

I. Hair of the beard, which gave 0.72 per cent. of ashes.

II. Hair of the head (light coloured), which gave 0.3 per cent. of ashes.

III. Hair of the head of a Mexican (very black), which gave 2 per cent. of ashes. Iv. Brown hair from the head.

The analytical results were-

\begin{tabular}{|c|c|c|c|c|}
\hline 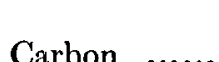 & $\begin{array}{c}1 . \\
51 \cdot 529\end{array}$ & $\begin{array}{l}\text { II. } \\
50 \cdot 652\end{array}$ & $\begin{array}{l}\text { III. } \\
49 \cdot 935\end{array}$ & $\begin{array}{c}\text { IV. } \\
50 \cdot 622\end{array}$ \\
\hline Hydrogen ... & 6.687 & 6.769 & 6.631 & 6.613 \\
\hline Vitrogen ....... & $17 \cdot 936$ & $17 \cdot 936$ & $17 \cdot 986$ & $17 \cdot 036$ \\
\hline $\begin{array}{l}\text { xygen and } \\
\text { Sulphur... }\end{array}$ & $23 \cdot 848$ & $24 \cdot 643$ & $25 \cdot 498$ & $24 \cdot 829$ \\
\hline & & 100.0 & $100 \cdot 000$ & 00.0 \\
\hline
\end{tabular}

C. Buffalo horn purified as the other substances, gave $0 \cdot 7$ per cent. of ashes.

With this and the hair, the relative volumes of nitrogen and carbonic acid were found to be 1:7 when chromate of lead was used.

The nitrogen was also determined by the method of Will and Plantamour to be 16.380 per cent., but came out 17.284 . by a direct determination.

The analytical results in four cases were-

\begin{tabular}{|c|c|c|c|c|}
\hline C & $\begin{array}{c}\text { r. } \\
51 \cdot 990\end{array}$ & $\begin{array}{l}\text { II. } \\
51 \cdot 162\end{array}$ & $\begin{array}{c}\text { IIr: } \\
51 \cdot 620\end{array}$ & $\begin{array}{l}\text { IV. } \\
51 \cdot 540\end{array}$ \\
\hline Hydrogen ... & $6 \cdot 717$ & $6 \cdot 597$ & $6 \cdot 754$ & 6.779 \\
\hline Nitrogen...... & $17 \cdot 284$ & $17 \cdot 284$ & $17 \cdot 284$ & $17 \cdot 284$ \\
\hline Oxygen and $\}$ & $24 \cdot 009$ & $24 \cdot 957$ & $24 \cdot 342$ & $24 \cdot 397$ \\
\hline & 10 & $100 \cdot 000$ & $100 \cdot 000$ & $00 \cdot 000$ \\
\hline
\end{tabular}

Nails and wool purified as usual gave the following results :-

\begin{tabular}{|c|c|c|}
\hline 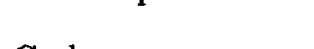 & Nails. & Wool. \\
\hline Carbon ................ & $51 \cdot 089$ & $50 \cdot 653$ \\
\hline Hydrogen ............ & 6.824 & $7 \cdot 029$ \\
\hline Nitrogen & $16 \bullet 901$ & $17 \cdot 710$ \\
\hline Oxygen and sulphu & $25 \cdot 186$ & $24 \cdot 608$ \\
\hline & $\overline{100 \cdot 000}$ & $\overline{100 \cdot 000}$ \\
\hline
\end{tabular}


If we seek to establish for these horny tissues a formula comparable with that of protein, we may best adopt $\mathrm{C}_{48} \mathrm{H}_{39} \mathrm{~N}_{7} \mathrm{O}_{17}$, from which if we subtract protein $\left(\mathrm{C}_{48} \mathrm{H}_{36} \mathrm{~N}_{6} \mathrm{O}_{14}\right)$ there remains $\mathrm{H}_{3} \mathrm{~N} \mathrm{O}_{3}$, or the horny material consists of protein $+\mathrm{NH}_{3}+3 \mathrm{O}$.

When horn, wool, or hair is dissolved in solution of potash, ammonia is evolved. On decomposing the liquor by sulphuric acid, removing the precipitate by filtration and distilling, a very sensible quantity of acetic acid may be obtained. If the alkaline solution be decomposed by acetic acid, sulphuretted hydrogen is evolved, and a precipitate formed which agrees perfectly with protein in its character and composition; but if this precipitate be removed and the liquor decomposed by a new quantity of acetic acid, a grayish solid separates which is of a different nature. Its composition, and that of protein from hair or horn, is as follows:-

\begin{tabular}{|c|c|c|}
\hline & $\begin{array}{l}\text { 1st precipitate, } \\
\text { true protein. }\end{array}$ & 2nd precipitate \\
\hline Carb & . $\quad 55 \cdot 408$ & 53.536 \\
\hline Hydrogen & $7 \cdot 238$ & 6.956 \\
\hline Nitrogen & . 15.593 & $14: 801$ \\
\hline Oxygen & - $21 \cdot 761$ & $24 \cdot 707$ \\
\hline & $100 \cdot 000$ & $100 \cdot 000$ \\
\hline
\end{tabular}

The membrane which encloses the albumen and lines the interior of the shell of the egg was found to be also a horny tissue.

\section{Feathers.}

This material, which is usually considered as horny, has been found by Dr. Scherer essentially distinct. It contains to the same carbon, hydrogen and nitrogen, an atom less of oxygen than true horn, the formulæe expressing the analytical results being $\mathrm{C}_{48} \mathrm{H}_{39} \mathrm{~N}_{7} \mathrm{O}_{16^{\circ}}$

\section{Black Pigment of the Eye.}

This substance, the details of the preparation of which in the pure state may be passed over, consists of

\begin{tabular}{|c|c|c|c|}
\hline & I. & II. & III. \\
\hline Carbo & 58.273 & 58.672 & 57.908 \\
\hline Hydrogen & $5 \cdot 973$ & $5 \cdot 962$ & $5 \cdot 817$ \\
\hline Nitrogen & $13 \cdot 768$ & $13 \cdot 768$ & $13 \cdot 768$ \\
\hline Oxygen & $21 \cdot 986$ & $21 \cdot 598$ & $22 \cdot 507$ \\
\hline & 100.000 & $100 \cdot 000$ & $\overline{100 \cdot 000}$ \\
\hline
\end{tabular}

Phil. Mag. S. 3. Vol. 20. No. 132. May 1842. 